\title{
BEZPIECZEŃSTWO SOCJALNE OSÓB BEZROBOTNYCH W POLSCE NA TLE SYTUACJI W UNII EUROPEJSKIEJ
}

Bezpieczeństwo socjalne osób dotkniętych zjawiskiem bezrobocia i ich rodzin zapewniane jest z wykorzystaniem różnorodnych instrumentów zarówno pieniężnych, jak i w postaci wsparcia rzeczowego. Niezależnie od tego, jakie występują proporcje stosowania określonych form wsparcia w poszczególnych państwach, zazwyczaj wypłaca się świadczenia w ramach systemu ubezpieczeniowego oraz zaopatrzeniowego. Podstawową formę wsparcia ekonomicznego osób, które utraciły prace stanowią przede wszystkim zasiłki, które wypłacane są głównie w ramach przynależności do systemu ubezpieczeń społecznych na podstawie opłacania składek lub spełniania określonych ustawowo kryteriów, jednak najczęściej niezależnych od sytuacji majątkowej bezrobotnego. Wsparcie w ramach systemu świadczeń zaopatrzeniowych z kolei, nie ma charakteru roszczeniowego, a jedynie uznaniowy. W tym przypadku, o przyznaniu świadczenia decyduje sytuacja bytowa bezrobotnego i jego rodziny. Jako podstawową formę zabezpieczenia socjalnego bezrobotnych w każdym systemie traktuje się jednak zasiłki.

System zasiłków dla bezrobotnych powinien być tak skonstruowany, żeby skutecznie spełniał dwie zasadnicze funkcje. Pierwsza podstawowa funkcja, która stanowi jednocześnie główną przyczynę wprowadzenia zasiłków, to zabezpieczenie socjalne w przypadku utraty pracy i dochodów z nią związanych. W niektórych państwach zasiłki mają stanowić jak największą rekompensatę utraconych dochodów, tak by w minimalnym zakresie dochodziło do obniżenia stopy życiowej osoby bezrobotnej i jej rodzin, w skrajnie odmiennych rozwiązaniach, zasiłki mają jedynie dostarczać dochodu niezbędnego dla zaspokojenia potrzeb egzystencjalnych.

Drugą funkcją, którą powinny spełniać zasiłki, jest zachowanie motywacji do poszukiwania zatrudnienia przez osoby bezrobotne. W tym przypadku kluczowe znaczenie odgrywa zróżnicowanie poziomu zasiłków i potencjalnych wynagrodzeń za pracę. Często podkreśla się, że skuteczne zabezpieczenie socjalne bezrobotnych jest odwrotnie proporcjonalne do siły motywacji osób pozbawionych pracy do jej poszukiwania.

W literaturze przedmiotu spotkać można dwa przeciwstawne kierunki interpretacji związków poziomu zasiłków i stopy bezrobocia.

Neoklasycy wskazywali, że główną przyczynę braku równowagi na rynku pracy należy upatrywać w systemie ubezpieczeń od bezrobocia, który dynamicznie rozwijał się w szczególności w pierwszych dekadach XX wieku. Wytłumaczenie takie promowali Arthur C. Pigou, Henry Clay. Podkreślali, że wprowadzenie zasiłków dla bezrobotnych, zmobilizowało związki zawodowe do formułowania postulatów płacowych, co 
z kolei prowadziło do wzrostu kosztów pracy, a przez to do ograniczenia popytu na pracę, co bezpośrednio implikuje wzrost stopy bezrobocia (Kwiatkowski: 159). Ponadto zasiłki ich zdaniem, łagodzą skutki występowania bezrobocia, co w konsekwencji zmniejsza skłonność do przyjmowania mniej satysfakcjonujących ofert pracy, wydłużając tym samym okres pozostawania bez pracy. Poza tym, fundusz ubezpieczeniowy, tworzony przez wpłaty pracodawców, a z którego wypłacane są zasiłki, podnosi koszty pracy, co wpływa na ograniczenie popytu na pracę (Clay, 1929: 335).

Zwolennicy powyższego sposobu myślenia dochodzą do wniosku, że skutecznym sposobem na ograniczanie bezrobocia jest maksymalna redukcja poziomu zasiłków $\mathrm{i}$ innych form zabezpieczenia socjalnego.

W latach 30. XX wieku wraz ze sformułowaniem teorii przez Johna M. Keynesa doszło do konfliktu intelektualnego z podejściem neoklasycznym. Keynes, poddając zdecydowanej krytyce poglądy ekonomistów klasycznych i neoklasycznych, dowodził, że realizacja polityki w oparciu o koncepcje ortodoksyjne nie przystaje do uwarunkowań ówczesnej rzeczywistości. Szczególnym przykładem nieprzystawania teorii klasycznej do rzeczywistości gospodarczej był okres wielkiego, światowego kryzysu gospodarczego lat 30. XX wieku. Czas ten pokazał, że „niewidzialna ręka rynku” w dobie głębokiego załamania gospodarki jest bezsilna. Przedstawiciele ortodoksyjnej ekonomii neoklasycznej bezkompromisowo wierzyli w samoczynne działanie rynku w każdej fazie cyklicznego rozwoju, a więc również w okresie kryzysu, nawet gdy „niewidzialna ręka” nie wykazywała skuteczności i nie wpływała na odwrócenie trendu. Takie pojmowanie samoregulacyjnych mechanizmów rynkowych jako gwaranta rozwoju stanowiło podstawę krytyki ze strony Keynesa. Uważał on, że bierna postawa „państwa” decyduje o pogłębianiu dekoniunktury gospodarczej (Bludnik, 2012: 27-31), co z kolei determinuje pogarszanie się sytuacji na rynku pracy.

Przeciwnie niż klasycy, J. M. Keynes uważał, że bezrobocie nie ma charakteru dobrowolnego, lecz przymusowy, co wynika przede wszystkim z ograniczonej elastyczności płac. W myśl swej teorii uważał, że na poziom zatrudnienia wpływają głównie skłonność do konsumpcji i stopa nowych inwestycji. Zakładał, że przy danej skłonności do konsumpcji zatrudnienie może wzrastać jedynie wówczas, gdy rośnie poziom inwestycji. Odmiennie, niż to czynili przedstawiciele ekonomi tradycyjnej, Keynes nie postrzegał poziomu podaży siły roboczej jako podstawowego czynnika decydującego o stanie lub braku równowagi na rynku pracy. Nie oznacza to, że nie interesowały go rozmiary podaży pracy, lecz za istotniejsze determinanty uważał z jednej strony poziom kwalifikacji, techniki, technologii, a z drugiej gusty konsumentów oraz strukturę społeczną (Keynes: 225-228; Acocella, 2002: 155-156). Takie podejście powodowało, że Keynes dowodził, że zasiłki w okresie dekoniunktury gospodarczej, przy rosnącym bezrobociu powinny być zwiększane. Nie podzielał zatem poglądów neoklasyków, świadczących, że wysokie zasiłki implikują wzrost bezrobocia, koncentrował się bowiem na ich roli jako kreatorów popytu. Uważał, że w szczególności bezrobotni i najubożsi są najbardziej skłonni do konsumpcji, dlatego należy podnosić poziom zasiłków, co prowadzi do globalnego wzrostu zdolności konsumpcyjnych i przyczynia się do ożywienia gospodarki, a w konsekwencji do redukcji bezrobocia.

W kolejnych latach poglądy na temat relacji zasiłki-bezrobocie ulegały licznym modyfikacjom, ale każdy z nich można określić jako bliższy neoklasycznemu lub key- 
nesowskiemu punktowi widzenia. W 2010 Nagrodę Nobla przyznano za wyniki badań, które miały rozstrzygnąc spór, wskazując zdecydowanie, że to neoklasycy mieli rację. Peter Diamond, Dale Mortensen i Christopher Pissarides opracowali teorię, która interpretuje wpływ polityki gospodarczej, niektórych regulacji rynku, w tym zasiłków na poziom bezrobocia, płace i liczbę wakatów. Na podstawie swych badań sformułowali jednoznaczny wniosek, że im wyższe zasiłki dla bezrobotnych, tym wyższe rozmiary bezrobocia i dłuższy czas pozostawania bez pracy. Poszukiwanie zatrudnienia wymaga czasu i zasobów, powodując „tarcia”. Mimo, że zarówno pracodawcy poszukują pracowników, jak i bezrobotni są chętni do pracy, to potrzeby jednych i drugich nie są w pełni zaspokajane. W konsekwencji mamy do czynienia z równolegle występującym bezrobociem oraz wolnymi miejscami pracy ${ }^{1}$ (Jasiński: 1-4).

W praktyce funkcjonowania rynków pracy można jednak wskazać na liczne przykłady, które stanowią zaprzeczenie tak wyraźnie sformułowanym wnioskom. Dotyczy to państw, które z powodzeniem wdrażają zasady flexicurity ${ }^{2}$. Modelowe rozwiązania zastosowane np. w Danii pokazują, że można utrzymywać wysoki poziom bezpieczeństwa socjalnego bezrobotnych i jednocześnie skutecznie równoważyć podaż i popyt na pracę. W systemie tym postawiono na wysoką elastyczność rynku pracy, która implikuje brak stabilizacji zatrudnia, wysoki stopień niepewności rynkowej pracowników. Duńscy pracownicy i związkowcy akceptują jednak taki stan, gdyż słaba ochrona miejsc pracy jest rekompensowana rozbudowanym system zabezpieczenia społecznego. Gwarantuje on wysokie bezpieczeństwo dochodu w przypadku utraty pracy (również w przypadku choroby czy też wypadku). Mimo, że zapisywanie do funduszy ubezpieczeniowych jest dobrowolne, to większość pracowników chętnie z tego korzysta. Wraz $z$ utrata pracy, ubezpieczonym wypłacany jest zasiłek w pełnym wymiarze (ubezpieczenie przez okres 52 tygodni) w wysokości $90 \%$ płacy z poprzednich 12 tygodni. Zasiłki mogą być dodatkowo przyznawane przez komunę - lokalny samorząd, takie wypłaty uzależnione są od sytuacji bytowej, rodzinnej bezrobotnego. Czas wypłacania zasiłku wynosi cztery lata, a jego poziom pozostaje raczej stabilny przez ten okres. Osłona socjalna w Danii powiązana jest $\mathrm{z}$ aktywizacją zawodową. Wprawdzie w pierwszych 12 miesiącach od utraty pracy, bezrobotny zobligowany jest jedynie do jej aktywnego poszukiwania, ale później ma obowiązek uczestnictwa w aktywnych programach rynku pracy w pełnym wymiarze (osoby poniżej 25 roku życia zobowiązane są już po 6 miesiącach przebywania na zasiłku) (Lang).

Należące do najwyższych na świecie wydatki na politykę rynku pracy (wydatki publiczne w wysokości 4,42\% PKB w 2003 r.), a także wysokie obciążenia fiskalne - na poziomie $49 \%$ PKB, są gwarancją skuteczności duńskiego systemu flexicurity. Powoduje to, że Duńczycy czują się bezpieczni i są skłonni zaakceptować niskie bezpieczeństwo zatrudnienia, któremu towarzyszy możliwość kilkakrotnej utraty pracy w trakcie kariery zawodowej (Mendza-Drozd).

\footnotetext{
1 Diamond opracował ramy teoretyczne dla rynków poszukiwania, natomiast Mortensen oraz Pissarides rozwinęli i zastosowali tę teorię do rynku pracy.

${ }^{2}$ Połączenie elastyczności rynku pracy i bezpieczeństwa zatrudnienia, rozumianego również jako relatywnie (do wcześniej uzyskiwanych wynagrodzeń) wysokich zasiłków dla bezrobotnych.
} 
W niemieckim modelu flexicurity dla porównania, występuje wysoki stopień bezpieczeństwa zatrudnienia, co oznacza, że bardzo trudno jest zwalniać pracowników i przyjmować do pracy nowych. W związku z tym Niemcom trudno jest stosować tzw. „elastyczność zewnętrzną”, wdrażają zatem elastyczność wewnętrzną. W Danii nie występuje duża elastyczność płacowa i czasowa (czas pracy), co stanowi domenę rozwiązań niemieckich.

Przykład niemiecki ponadto nie pozwala, tak jak przykład duński, podważyć wniosków sformułowanych przez Mortensena i Pissaridesa. Reformy Hartza, które przewidywały m.in. redukcję poziomów zasiłków przyczyniły się do redukcji bezrobocia. Tym niemniej jednak nie można udowodnić, że to właśnie redukcja zasiłków spowodowała ograniczenie nierównowagi na rynku pracy, gdyż pakiet reform zawierał wiele elementów uelastyczniających bardzo sztywny wcześniej, niemiecki rynek pracy.

W polskim systemie warunki dostępu do korzystania ze świadczeń oraz wysokość przeznaczanych na ten cel środków zależą od regulacji ustawowych i corocznie uchwalanych ustawach budżetowych (mimo, że dystrybucją zasiłków zajmują się powiaty, a wsparciem z zakresu pomocy społecznej głównie gminy, wielkość wsparcia zależy od poziomu przewidzianych subwencji i dotacji określonych w budżecie krajowym). W Konstytucji Rzeczypospolitej Polskiej z 2 kwietnia 1997 r. zawarto zapisy dające obywatelom prawo do „zabezpieczenia społecznego w razie niezdolności do pracy ze względu na chorobę lub inwalidztwo oraz po osiagnięciu wieku emerytalnego". Ponadto zapisy ustawy zasadniczej gwarantują obywatelom, że: ,pozostający bez pracy nie z własnej woli i niemający innych środków utrzymania ma prawo do zabezpieczenia społecznego" (Konstytucja, 1997).

Zgodnie z obowiązującą ustawą o promocji zatrudnienia i instytucjach rynku pracy, prawo do zasiłku przysługuje bezrobotnemu za każdy dzień kalendarzowy po upływie 7 dni od dnia zarejestrowania się we właściwym powiatowym urzędzie pracy, o ile: nie ma dla niego propozycji odpowiedniej pracy, propozycji stażu, przygotowania zawodowego dorosłych, szkolenia, prac interwencyjnych lub robót publicznych; w okresie 18 miesięcy poprzedzających dzień zarejestrowania, łącznie przez okres co najmniej 365 dni pracowali i otrzymywali wynagrodzenie w kwocie co najmniej minimalnego wynagrodzenia za pracę, od którego istnieje obowiązek opłacania składki na Fundusz Pracy, z pewnymi wyjątkami (Ustawa o promocji zatrudnienia).

Osoby, których okres uprawniający do zasiłku wynosi co najmniej 20 lat otrzymują $120 \%$ wysokości zasiłku. Bezrobotni mogą pobierać zasiłek przez okres do 6 i do 12 miesięcy. Dwunastomiesięczny okres pobierania zasiłku jest uzależniony od: poziomu stopy bezrobocia w powiecie zamieszkania bezrobotnego - gdy w danym powiecie, w dniu 30. czerwca poprzedniego roku stopa bezrobocia przekraczała $150 \%$ przeciętnej stopy bezrobocia w kraju; wieku i długości okresu uprawniającego do zasiłku - wiek ponad 50 lat i co najmniej dwudziestoletni okres uprawniający do zasiłku; posiadania co najmniej jednego dziecka w wieku do 15 lat, a także współmałżonka, który również jest bezrobotny i utracił prawo do zasiłku z powodu upływu okresu jego pobierania po dniu nabycia prawa do zasiłku przez bezrobotnego, któremu zasiłek z tego tytułu przysługuje (Ustawa o promocji zatrudnienia).

Ustawa o promocji zatrudnienia i instytucjach rynku pracy przewiduje również instrumenty rynku pracy, mające na celu wspieranie bezrobotnych. Wsparcie socjalne 
polega również na finansowaniu kosztów przejazdu do pracodawcy zgłaszającego ofertę pracy lub do miejsca pracy, odbywania stażu, przygotowania zawodowego dorosłych lub odbywania zajęć w zakresie poradnictwa zawodowego lub pomocy w aktywnym poszukiwaniu pracy $\mathrm{w}$ związku ze skierowaniem przez powiatowy urząd pracy; finansowaniu kosztów zakwaterowania w miejscu pracy osobie, która podjęła zatrudnienie lub inną pracę zarobkową, staż, przygotowanie zawodowe dorosłych poza miejscem stałego zamieszkania, w przypadku skierowania przez powiatowy urząd pracy; dofinansowaniu wyposażenia miejsca pracy, podjęcia działalności gospodarczej, kosztów pomocy prawnej, konsultacji i doradztwa; refundowaniu kosztów poniesionych z tytułu opłaconych składek na ubezpieczenia społeczne w związku z zatrudnieniem skierowanego bezrobotnego; finansowaniu dodatków aktywizacyjnych; finansowaniu kosztów zorganizowanego przejazdu bezrobotnych i poszukujących pracy, w związku z udziałem tych osób w targach pracy i giełdach pracy organizowanych przez wojewódzki urząd pracy w ramach pośrednictwa pracy, w szczególności prowadzonego w ramach sieci EURES (Ustawa o promocji zatrudnienia).

Wsparciem spełniającym kryteria flexicurity, czyli zawierającym w sobie działania w zakresie social security i flexibility jest wsparcie oferowane bezrobotnym samotnie wychowującym co najmniej jedno dziecko do 7. roku życia. Mianowicie, zgodnie $\mathrm{z}$ ustawą o promocji zatrudnienia i instytucjach rynku pracy, Starosta może, po udokumentowaniu poniesionych kosztów, refundować koszty opieki nad dzieckiem lub dziećmi do lat $7 \mathrm{w}$ wysokości uzgodnionej, nie wyższej jednak niż połowa zasiłku na każde dziecko, na opiekę którego poniesiono koszty, jeżeli bezrobotny podejmie zatrudnienie lub inną pracę zarobkową lub zostanie skierowany na staż, przygotowanie zawodowe dorosłych lub szkolenie oraz pod warunkiem osiagania z tego tytułu miesięcznie przychodów nieprzekraczających minimalnego wynagrodzenia za pracę (Ustawa o promocji zatrudnienia).

Analizując związek prawa do zasiłku i aktywności oraz skuteczności w poszukiwaniu pracy przez bezrobotnych w Polsce można na podstawie badań sformułować kilka zasadniczych wniosków. Wpisują się one we wspomnianą teorię poszukiwań, sformułowaną przez noblistów Mortensena i Pissaridesa. Mianowicie: bezrobotni pobierający zasiłek o $18 \%$ częściej niż bezrobotni bez prawa do zasiłku charakteryzują się bierną postawą na rynku pracy. Wśród długotrwale bezrobotnych posiadanie prawa do zasiłku zwiększa prawdopodobieństwo bycia biernym aż o 76\%. Zasiłki zatem opóźniają czas wychodzenia z bezrobocia, co może ograniczać szanse i utrudniać powrót do zatrudnienia; Wśród bezrobotnych pozostających bez pracy nie dłużej niż 6 miesięcy, zasiłkobiorcy mają o $26 \%$ niższe szanse podjęcia pracy niż bezrobotni bez prawa do zasiłku. Zasiłkobiorcy poszukują ofert pracy z wyższymi płacami niż osoby pozbawione prawa do zasiłku. Dotyczy to w szczególności bezrobotnych z dłuższym okresem pozostawania bez pracy (powyżej 6 miesięcy). Warto podkreślić, że wprowadzona w 2010 roku zasada degresji wysokości zasiłków w kolejnych miesiącach bezrobocia sprzyja wzrostowi znaczenia funkcji motywacyjnej zasiłków (Kwiatkowski i in.), co powoduje, że nie tylko spełniają one funkcje socjalne. Należy jednak zauważyć, że wysokość zasiłków dla bezrobotnych w Polsce zarówno w wymiarze nominalnym, jak i względnym w stosunku do płacy minimalnej należy do najniższych w UE, co czyni je z natury spełniającymi funkcję motywacyjną. 
Obok systemu zasiłków bezpieczeństwo socjalne bezrobotnych w Polsce jest zapewniane poprzez funkcjonowanie systemu pomocy społecznej. Dla korzystania ze wsparcia pomocy społecznej konieczne jest zarejestrowanie się w urzędzie pracy, co reguluje zapis ustawy o pomocy społecznej, dotyczący zasiłku okresowego. Ograniczenie stanowi jednak kryterium dochodowe. Pozbawić uprawnień mogą zatem nawet stypendia przyznawane w okresie szkoleń, stażu czy przygotowania zawodowego w miejscu pracy, czy też wynagrodzenia w wypadku prac interwencyjnych i robót publicznych. Tylko w wypadku prac społecznie użytecznych dochody uzyskane przez klienta pomocy społecznej, będącego jednocześnie osobą bezrobotną, nie są wliczane do dochodu. Pozbawienie prawa do wsparcia z pomocy społecznej dotyczyć może także uczestników działań w ramach projektów Programu Operacyjnego Kapitał Ludzki $(\mathrm{PO} \mathrm{KL})^{3}$.

Warto zwrócić uwagę na wysoki stopień zróżnicowania wydatków na zabezpieczenie socjalne bezrobotnych w poszczególnych państwach Unii Europejskiej. Różnice nie wynikająjedynie ze zróżnicowań w poziomach rozwoju poszczególnych gospodarek, ale ze specyfiki realizowanej polityki rynku pracy. Zmiany w poziomie zabezpieczenia socjalnego bezrobotnych obrazuje tabela 1 .

Tabela 1

Podstawowe zabezpieczenie socjalne bezrobotnych w państwach UE w latach 2004 i 2011

\begin{tabular}{|c|c|c|c|c|c|c|}
\hline \multirow{3}{*}{$\begin{array}{c}\text { Państwo \czas } \\
1\end{array}$} & \multicolumn{4}{|c|}{$\begin{array}{c}\text { Wsparcie socjalne bezrobotnych (głównie } \\
\text { zasiłki i wcześniejsze emerytury) jako \% } \\
\text { PKB }\end{array}$} & \multicolumn{2}{|c|}{$\begin{array}{c}\text { Zharmonizowana } \\
\text { stopa bezrobocia (\%) }\end{array}$} \\
\hline & \multicolumn{2}{|c|}{2004} & \multicolumn{2}{|c|}{2011} & \multirow{2}{*}{$\frac{2004 M 12}{6}$} & \multirow{2}{*}{$\frac{2011 M 12}{7}$} \\
\hline & 2 & 3 & 4 & 5 & & \\
\hline Belgia & 3,416 & (d) & 3,682 & (d) & 8,2 & 7,2 \\
\hline Bułgaria & 0,776 & & 0,593 & & 11,4 & 11,7 \\
\hline Republika Czeska & 0,484 & & 0,556 & & 8,1 & 6,5 \\
\hline Dania & 4,337 & (e) & 3,730 & (e) & 5,3 & 7,6 \\
\hline Niemcy & 3,418 & & 1,808 & (e) & 11,2 & 5,6 \\
\hline Estonia & 0,234 & & 0,719 & (e) & 8,8 & 10,9 \\
\hline Irlandia & 1,585 & & 3,491 & & 4,4 & 15,0 \\
\hline Grecja & 0,564 & (e) & 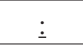 & & 10,2 & 21,4 \\
\hline Hiszpania & 2,126 & & 3,694 & & 10,3 & 23,2 \\
\hline Francja & 2,675 & & 2,336 & & 9,3 & 9,8 \\
\hline Włochy & 1,285 & & 1,703 & & 7,9 & 9,5 \\
\hline Cypr & $\vdots$ & & 1,030 & $(\mathrm{p})$ & 5,2 & 9,8 \\
\hline Łotwa & 0,507 & & 0,686 & & 10,5 & 15,6 \\
\hline Litwa & 0,304 & & 0,559 & (e) & 10,4 & 13,6 \\
\hline Luksemburg & 1,050 & (e) & 1,150 & & 4,9 & 4,9 \\
\hline Węgry & 0,693 & (e) & 1,022 & (e) & 6,5 & 10,9 \\
\hline Malta & $\vdots$ & & 0,483 & & 6,9 & 6,5 \\
\hline
\end{tabular}

3 Ustawa o pomocy społecznej. 


\begin{tabular}{||l|c|c|c|c|c|c||}
\hline \multicolumn{1}{|c|}{1} & 2 & 3 & 4 & 5 & 6 & 7 \\
\hline Holandia & 3,448 & (e) & 2,714 & (e) & 5,3 & 4,9 \\
\hline Austria & 2,030 & & 2,043 & & 5,0 & 4,2 \\
\hline Polska & 0,857 & (a) & 0,722 & (e) & 18,3 & 9,9 \\
\hline Portugalia & 1,827 & & 1,910 & & 7,9 & 14,5 \\
\hline Rumunia & 0,626 & & 0,295 & & 7,8 & 7,4 \\
\hline Słowenia & 0,391 & (a) & 1,227 & & 6,4 & 8,6 \\
\hline Słowacja & 0,502 & & 0,791 & & 17,6 & 14,0 \\
\hline Finlandia & 2,964 & & 2,456 & & 8,7 & 7,6 \\
\hline Szwecja & 2,435 & & 1,685 & (e) & 7,5 & 7,8 \\
\hline Wielka Brytania & 0,638 & (e) & 0,303 & (b) & 4,8 & 8,3 \\
\hline Norwegia & 1,609 & & 0,408 & & 4,4 & 3,3 \\
\hline
\end{tabular}

a - dane z roku 2005;

$\mathrm{b}$ - dane $\mathrm{z}$ roku 2010;

e - wartość przybliżona;

$\mathrm{d}$ - według krajowej definicji;

$\mathrm{p}$ - wartość niezweryfikowana.

Źródlo: Eurostat, http://epp.eurostat.ec.europa.eu/portal/page/portal/eurostat/home/, 10.01.2014.

Analizując dane zawarte w tabeli 1., można również przyznać rację Mortensenowi i Pissaridesowi, gdyż największy wzrost bezrobocia w badanych latach zanotowały te państwa, które w największym stopniu zwiększyły środki na socjalne osłony dla bezrobotnych. Wśród nich wyróżnić należy: Irlandię, gdzie wydatki na wsparcie socjalne bezrobotnych wzrosło z blisko 1,6\% do niemal 3,5\% PKB, a bezrobocie w tym czasie wzrosło z 4,4\% do 15\%. W Hiszpanii wydatki na ten cel się niemal podwoiły, rosnąc z 2,1\% do 3,7\% PKB, a stopa bezrobocia wzrosła z 10,3\% do 23,2\%. W Słowenii wydatki na zasiłki zostały niemal potrojone (z niemal 0,4\% do 1,2\% PKB), podczas gdy bezrobocie wzrosło z $6,4 \%$ do $8,6 \%$. Te państwa z kolei, które ograniczyły wydatki na zasiłki lub utrzymały je na w miarę stabilnym poziomie utrzymały relatywną stabilność na rynku pracy lub nawet zanotowały spadek bezrobocia. Należą do nich: Bułgaria, Dania, Niemcy, Francja, Holandia, Polska, Rumunia, Finlandia, Szwecja i Norwegia. Na uwagę zasługuje w szczególności przypadek Niemiec, gdzie bezrobocie w badanym okresie uległo redukcji z $11,2 \%$ do $5,6 \%$ przy jednoczesnej redukcji wydatków na zasiłki z 3,4\% do 1,8\% PKB. W tym miejscu należy zaznaczyć, że przyczyn tak znaczącej poprawy sytuacji w zakresie równowagi między podażą i popytem na pracę nie należy przypisywać jedynie ograniczeniu poziomu zasiłków, ale i innym reformom rynku pracy przeprowadzonym w ramach Hartz IV.

W powyższym zestawieniu znaleźć można także odmienne od powyższej reguły związki pomiędzy stopą bezrobocia i poziomem wydatków przeznaczanych na socjalne zabezpieczenie bezrobotnych. Przykład w tym miejscu stanowi Wielka Brytania, gdzie wydatki na zasiłki ograniczono z $0,64 \%$ do $0,3 \%$ PKB, a bezrobocie w tym czasie wzrosło z 4,8\% do 8,3\% oraz Słowacja, gdzie z kolei wzrostowi wydatków na zasiłki towarzyszył spadek bezrobocia.

Bez wątpienia, liczniej zaprezentowane przykłady wpisują się w teorię Mortensena i Pissaridesa, co stanowi ilustrację dla wyników ich badań. Tym niemniej jednak, w zdecydowanej większości przypadków związki, które są przedmiotem powyższej 
analizy ukształtowały się nie tyle pod wpływem sugerowanej przez teorię zależności, a pod wpływem światowego kryzysu gospodarczego, który dotknął również państwa Unii Europejskiej. Oznacza to, że recesja gospodarcza lub wyraźne spowolnienie rozwoju wywołały dynamiczny wzrost liczby bezrobotnych, w następstwie czego intensywnie rosły wydatki na politykę osłonowa, w tym przede wszystkim na zasiłki. Wzrost bezrobocia miał zatem charakter pierwotny w stosunku do wzrostu wydatków na zasiłki. Nie można w związku z tym, traktować obserwowanej zależności, jako dowodu na słuszność analizowanej teorii Mortensena i Pissaridesa. Idąc dalej torem myślenia wspomnianych autorów, można jedynie przypuszczać, że gdyby bezpieczeństwo socjalne uległo mimo wszystko redukcji lub redystrybucji na większą liczbę beneficjentów, to czas pozostawania bez pracy uległby skróceniu i wskaźniki bezrobocia byłyby niższe. W sytuacji recesji lub powolnego wzrostu, który obserwować można w większości państw UE trudno przypuszczać, że niskie zabezpieczenie socjalne byłoby wystarczającym argumentem dla tworzenia licznych, nowych miejsc pracy. Można wprawdzie zakładać, że niższa osłona socjalna motywowałaby do przyjmowania ofert pracy za niższe stawki, co obniżałoby koszty pracy, zachęcając pracodawców do zatrudniania. Pamiętać należy jednak, że w takiej samej sytuacji znaleźliby się na danym rynku pracy także inni pracodawcy, którzy mogliby zyskać tańszą siłę roboczą. Wynika stąd, że trudno byłoby uzyskać przewagę konkurencyjną, a globalnie niższe płace prowadziłyby do ograniczenia popytu, który pogłębiałby recesję lub wydłużał okres stagnacji gospodarczej.

Jak wynika z tabeli 1., Polska znajduje się obecnie na 17 miejscu w UE pod względem udziału wydatków publicznych przeznaczanych na zasiłki dla bezrobotnych w stosunku do PKB. Zajmuje jednocześnie ostatnie miejsce, pod względem udziału wydatków na cele walki z bezrobociem i zasiłków dla bezrobotnych w ogóle wszystkich środków przeznaczanych na cele społeczne (1,5\%). Średnia w Unii Europejskiej w tym zakresie wynosi 5,6\%. Dodać należy, że poza tak niewielkim udziałem wydatków na cele związane z przeciwdziałaniem bezrobociu w puli wydatków socjalnych w Polsce, sam poziom wydatków socjalnych w stosunku do PKB należy do najniższych w UE, co wyraźnie obrazuje tabela 2.

Tabela 2

Wydatki na zabezpieczenie społeczne

\begin{tabular}{|c|c|c|c|c|c|c|c|c|c|}
\hline & \multicolumn{3}{|c|}{$\begin{array}{l}\text { Wydatki } \\
\text { w \% PKB }\end{array}$} & \multicolumn{6}{|c|}{$\begin{array}{c}\text { Świadczenia według przeznaczenia } \\
\text { w \% ogółu świadczeń socjalnych }\end{array}$} \\
\hline & 2007 & 2009 & 2010 & $\begin{array}{c}\text { PPS per } \\
\text { capita UE } \\
27=100\end{array}$ & $\begin{array}{l}\text { emerytal- } \\
\text { no-rynko- } \\
\text { we }\end{array}$ & $\begin{array}{c}\text { opieka } \\
\text { zdrowotna } \\
\text { /niepelno- } \\
\text { sprawni }\end{array}$ & $\begin{array}{c}\text { rodzi- } \\
\text { ny i } \\
\text { dzieci }\end{array}$ & $\begin{array}{c}\text { bezro- } \\
\text { bocie }\end{array}$ & $\begin{array}{l}\text { bezdom- } \\
\text { ność i wy- } \\
\text { kluczenie } \\
\text { społeczne }\end{array}$ \\
\hline 1 & 2 & 3 & 4 & 5 & 6 & 7 & 8 & 9 & 10 \\
\hline UE 27 & 26,1 & 29,6 & 29,4 & 100 & 45,0 & 37,4 & 8,0 & 6,0 & 3,6 \\
\hline Belgia & 26,9 & 30,4 & 29,9 & 121 & 39,6 & 35,7 & 7,7 & 13,3 & 3,6 \\
\hline Bułgaria & 14,1 & 17,2 & 18,1 & 27 & 51,5 & 32,2 & 11,4 & 3,4 & 1,5 \\
\hline Czechy & 18,0 & 20,3 & 20,1 & 55 & 47,2 & 40,1 & 6,8 & 4,2 & 1,7 \\
\hline Dania & 28,8 & 33,2 & 33,3 & 143 & 37,7 & 37,4 & 12,4 & 7,5 & 5,0 \\
\hline
\end{tabular}




\begin{tabular}{|c|c|c|c|c|c|c|c|c|c|}
\hline 1 & 2 & 3 & 4 & 5 & 6 & 7 & 8 & 9 & 10 \\
\hline Niemcy & 27,9 & 31,5 & 30,7 & 124 & 40,2 & 40,4 & 10,9 & 5,8 & 2,7 \\
\hline Estonia & 12,1 & 19,3 & 18,1 & 39 & 44,2 & 37,7 & 12,7 & 4,2 & 1,1 \\
\hline Irlandia & 18,9 & 27,4 & 29,6 & 129 & 23,4 & 48,0 & 12,9 & 12,4 & 3,3 \\
\hline Grecja & 24,8 & 28,0 & 29,1 & 87 & 50,1 & 33,9 & 6,4 & 6,1 & 3,6 \\
\hline Hiszpania & 20,7 & 25,3 & 25,7 & 87 & 42,4 & 35,7 & 6,0 & 14,1 & 1,8 \\
\hline Francja & 30,9 & 33,6 & 33,8 & 124 & 44,9 & 35,0 & 8,3 & 6,9 & 5,0 \\
\hline Włochy & 26,6 & 29,9 & 29,9 & 102 & 60,6 & 31,5 & 4,6 & 2,9 & 0,3 \\
\hline Cypr & 18,2 & 21,1 & 21,6 & 71 & 45,7 & 26,9 & 10,0 & 5,0 & 12,4 \\
\hline Lotwa & 11,3 & 16,9 & 17,8 & 31 & 53,5 & 28,4 & 8,5 & 7,4 & 2,2 \\
\hline Litwa & 14,4 & 21,2 & 19,1 & 37 & 44,0 & 35,8 & 11,9 & 4,4 & 3,9 \\
\hline Luxemburg & 19,3 & 24,0 & 22,7 & 207 & 36,2 & 36,9 & 17,8 & 5,6 & 3,6 \\
\hline Węgry & 22,7 & 23,5 & 23,1 & 51 & 46,4 & 33,7 & 13,0 & 4,0 & 2,9 \\
\hline Malta & 18,0 & 20,0 & 19,8 & 56 & 54,9 & 33,6 & 6,3 & 2,8 & 2,5 \\
\hline Holandia & 28,3 & 31,6 & 32,1 & 145 & 39,2 & 43,4 & 4,1 & 5,2 & 8,1 \\
\hline Austria & 27,8 & 30,6 & 30,4 & 130 & 49,6 & 32,8 & 10,4 & 5,7 & 1,5 \\
\hline Polska & 18,1 & 19,2 & 18,9 & 40 & 60,9 & 31,6 & 4,2 & 2,2 & 1,1 \\
\hline Portugalia & 23,9 & 27,0 & 27,0 & 73 & 51,7 & 35,6 & 5,7 & 5,7 & 1,3 \\
\hline Rumunia & 13,6 & 17,1 & 17,6 & 28 & 50,7 & 34,7 & 9,6 & 3,2 & 1,7 \\
\hline Słowenia & 21,3 & 24,2 & 24,8 & 72 & 46,3 & 39,6 & 8,9 & 2,8 & 2,4 \\
\hline Słowacja & 16,1 & 18,8 & 18,6 & 46 & 43,0 & 39,5 & 9,8 & 5,1 & 2,6 \\
\hline Finlandia & 25,4 & 30,4 & 30,6 & 119 & 39,2 & 37,3 & 11,1 & 8,2 & 4,2 \\
\hline Szwecja & 29,2 & 32,0 & 30,4 & 129 & 42,1 & 39,1 & 10,4 & 4,5 & 3,9 \\
\hline Wielka Bryt. & 25,0 & 28,9 & 28,0 & 107 & 42,3 & 41,8 & 6,9 & 2,7 & 6,4 \\
\hline Islandia & 21,4 & 25,4 & 24,5 & 93 & 23,5 & 49,4 & 12,9 & 6,8 & 7,4 \\
\hline Norwegia & 22,5 & 26,1 & 25,6 & 158 & 31,6 & 49,0 & 12,5 & 3,2 & 3,6 \\
\hline Szwajcaria & 25,2 & 26,9 & 26,6 & 138 & 48,8 & 38,4 & 5,2 & 4,3 & 3,3 \\
\hline Chorwacja & - & 20,8 & 20,8 & 42 & 37,7 & 51,5 & 8,1 & 2,3 & 0,3 \\
\hline Serbia & - & - & 24,6 & - & 53,7 & 35,2 & 5,4 & 3,6 & 2,1 \\
\hline
\end{tabular}

Źródło: Eurostat, http://epp.eurostat.ec.europa.eu/portal/page/portal/eurostat/home/, 10.01.2014.

Analizując bardziej szczegółowo poziom bezpieczeństwa bytowego bezrobotnych w poszczególnych państwach, należy wziąć pod uwagę stopę zastapienia wcześniej uzyskiwanych wynagrodzeń przez zasiłki dla bezrobotnych. Przeciętnie najmniej po utracie pracy tracą Duńczycy - ok. 10\% wcześniejszego wynagrodzenia, Szwedzi ok. $20 \%$. Zasiłki dla bezrobotnych zastępują wynagrodzenia Francuzom w ok. 75\%, a Holendrom i Hiszpanom w 70\%, niewiele mniej otrzymują po utracie pracy Portugalczycy $-65 \%$, Niemcy, Belgowie i Bułgarzy po $60 \%$, a polscy bezrobotni $17 \%$. Mniejsza stopa zastapienia wynagrodzenia przez zasiłek występuje jedynie w Wielkiej Brytanii 15\% (Eurostat). W związku z tym zauważyć należy, że i w tym przypadku bezpieczeństwo dochodowe Polaków związane z utratą pracy należy do najniższych w Unii Europejskiej. Można sformułować zatem wniosek, stanowiący rekomendację dla konieczności istotnego podniesienia poziomu zasiłków. Biorąc jednak pod uwagę demotywujący do poszukiwania pracy charakter zasiłków, co wykazały przytoczone wyniki badań, należałoby jednocześnie znacznie uszczelnić system weryfikacji osób, które są uprawnione 
do pobierania świadczeń i jednocześnie stworzyć skuteczniejsze zasady obligowania bezrobotnych do podejmowania pracy w ramach ofert oferowanych przez urząd pracy. Poza tym w przypadku wzrostu poziomu zasiłków konieczne byłoby jednoczesne podniesienie poziomu płacy minimalnej tak, by utrzymać proporcje, nie ograniczając działania funkcji motywacyjnej zasiłków. Ewentualny szybszy wzrost płacy minimalnej w Polsce mógłby nastapić przy wykorzystaniu funduszy publicznych, poprzez dofinansowanie pracodawców tak, by wzrost poziomu składek ubezpieczeniowych nie zwiększył kosztów pracy, których wzrost mogłyby ograniczyć motywacje pracodawców do tworzenia nowych miejsc pracy.

\section{Bibliografia}

Bludnik H. (2012), Keynes i powojenny keynesizm, w: Współczesne teorie ekonomiczne, (red.) M. Ratajczak, Poznań.

Clay H. (1929), The Public Regulation of Wages In Great Britain, ,The Economic Journal”, Vol. 155.

Eurostat, http://epp.eurostat.ec.europa.eu/portal/page/portal/eurostat/home/, 10.01.2014.

Jasiński L. J. (2012), Nobel 2010, czyli badania rynku z frykcjami, http://www.pte.pl/pliki/2/12/Jasinski-1.pdf, 10.01.2014.

Keynes J. M. (2003), Ogólna teoria zatrudnienia procentu i pieniqdza, Warszawa.

Konstytucja Rzeczypospolitej Polskiej (1997), Dz. U. nr 78, poz. 483.

Kwiatkowski E. i in. (2009), Flexicurity w Polsce. Diagnoza i rekomendacje. Ocena wdrożenia modelu flexicurity $w$ polskiej polityce rynku pracy oraz rekomendacje dalszych działań, IPiSS, materiał powielony, Warszawa.

Lang D., Duński model elastycznego bezpieczeństwa (flexicurity). Wzór do naśladowania?, tłum. R. Szarfenberg, http://www.rszarf.ips.uw.edu.pl, 3.01.2011.

Mendza-Drozd M. (2006), Elastyczność i pewność zatrudnienia, http://www.ngo.pl, 3.01.2011.

Social protection. EU27 spent 29.4\% of GDP on social protection in 2010 (2012), ,Eurostat News release", Vol. 165, http://epp.eurostat.ec.europa.eu/cache/ITY_PUBLIC/3-27112012-AP/EN/ 3-27112012-AP-EN.PDF, 10.01.2014.

Ustawa z dnia 20 kwietnia 2004 r. o promocji zatrudnienia i instytucjach rynku pracy (2004), Dz. U. Nr 99, poz. 1001 z późn. zm.

\section{STRESZCZENIE}

Bezpieczeństwo socjalne osób dotkniętych zjawiskiem bezrobocia i ich rodzin zapewniane jest $\mathrm{z}$ wykorzystaniem różnorodnych instrumentów zarówno pieniężnych, jak i w postaci wsparcia rzeczowego. Podstawowym elementem zabezpieczenia socjalnego jest jednak system zasiłków dla bezrobotnych. W literaturze przedmiotu można znaleźć przeciwstawne poglądy o roli funkcji motywacyjnej zasiłków i ich wpływie na poziom bezrobocia. Zwolennicy koncepcji neoklasycznych podkreślają negatywny wpływ wymiaru zasiłków na poziom bezrobocia i czas pozostawania bez pracy. Przedstawiciele nurtów keynesowskich z kolei wykazują, że nie ma negatywnej korelacji pomiędzy poziomem zasiłków i stopą bezrobocia. Względną zgodność badań i poglądów można dostrzec w obserwacjach i wnioskach dotyczących związków okresu poboru zasiłków i jego negatywnym wpływie na czas pozostawania bez pracy. Dowodem na słuszność 
takich wniosków stanowią zarówno globalne dane statystyki Eurostatu, jak i szczegółowe badania przeprowadzone w Niemczech (po reformach Hartza), a także polskie analizy wdrażania modelu flexicurity. Odmienne wnioski natomiast można sformułować po analizie przykładu duńskiego, który wskazuje, że można utrzymywać stabilizację na rynku pracy przy jednych z najwyższych na świecie zasiłkach dla bezrobotnych i długim okresie uprawnień do ich poboru. Model duński pokazuje, że można skutecznie łączyć elastyczność rynku pracy z wysokim stopniem bezpieczeństwa socjalnego.

\title{
THE SOCIAL SECURITY OF THE UNEMPLOYED IN POLAND VERSUS THE SITUATION IN THE EUROPEAN UNION
}

\begin{abstract}
The social security of people affected by unemployment, and their families, is provided by various means of monetary instruments and support in kind. The fundamental element of social security, however, is a system of unemployment benefits. The literature of the subject presents contradictory opinions on the motivational function of benefits and their influence on unemployment levels. Advocates of neoclassical concepts stress the adverse influence of benefits on the level of unemployment and the time out of work. Representatives of Keynesian thinking point to the lack of a negative correlation between the level of benefits and the unemployment rate. Relative agreement between studies and opinions can be found in the observations and conclusions concerning the relation between the length of time on benefits and its adverse impact on re-entering employment. These conclusions find corroboration in the global statistics of Eurostat, detailed studies conducted in Germany and the Polish analysis of the implementation of the flexicurity model. The opposite conclusions can be drawn from the analysis of the Danish example, which shows that labor market stability can be maintained while providing some of the highest unemployment benefits in the world and a long period of providing them.
\end{abstract}


